\title{
Revitalizing Higher Education in the Muslim World
}

\author{
AbdulHamid A. AbuSulayman \\ London and Washington, DC: The International Institute \\ of Islamic Thought, 2006. 41 pages.
}

AdbulHamid A. AbuSulayman's book is an important and much-needed publication in the field of Islamic social and educational sciences. In a very direct, easy-to-read, and simple language, the book introduces the current problematic situation of Islamic higher education and offers a practical solution. The presented solution is not based on theoretical insights and analysis only, as it offers the example of the International Islamic University Malaysia (IIUM) as a live, practical model. Through the extended metaphor of a sick person, the author, a prestigious Islamic educator and thinker, pictures the Muslim ummah as an ailing body that needs immediate treatment. Through his professionalism and expertise, he prescribes the remedy.

The book's first half provides the reader with a general overview of the current situation of the Muslim ummah's retarded position and explains how education and developing cognitive modules are particularly needed for the rescue mission.

A "nation" that contains about one-fifth of the world's population, covers an area extending from the Atlantic to the Pacific, and has an illustrious past of scientific discoveries now has a combined GNP (Gross National Product) less than that of France or Germany. This humiliating fact, according to AbuSulayman, speaks of the ummah's current ailment. The author points to underdevelopment, division, tyranny, oppression, and education as some of the maladies. Yet instead of treating the symptoms of such maladies, as many scholars tend to do, he calls attention to the need to search for the causes in order to devise a permanent treatment. One of the main causes that AbuSulayman discusses is the imitation and replication of western education, which is alien to the ummah's consciousness and cultural goals.

Where to begin? Abusulayman offers a rational answer to this question, one based on a comprehensive Islamic vision that defines each Muslim's relation with God and his/her worldly activity. He envisions the beginning in two major Islamic principals of faith, the lack of which may have led to the current sad state of affairs: tawhid (monotheism) and jihad. These two poles are needed to ensure spiritual and physical achievement. Tawhid, as explained by the author, is the person's willing submission to the only true God. This creed of oneness is responsible for strengthening the ummah's conscience and turning all aspects of a Muslim's life in one direction: serv- 
ice and submission to God. Jihad, the most misunderstood and tabooed term nowadays, means striving physically and spiritually to meet the obligation of submitting to God, self-purification from associating anyone or anything with God, seeking sustenance, and exerting oneself to maintain private and public life. Based on quotations from the Qur'an, the author concludes that a Muslim's life should be a continuous act of worship dedicated to God both in worship and in seeking knowledge.

The author also concludes that the ummah will not progress or take its proper place among the world community without reforming and revitalizing its higher education. Here, he asks where higher education stands within the Islamic cultural reform project and how it should be revitalized and allowed to play its assigned role. To answer such questions, he calls for the Islamization of knowledge so that both "divine and human resources are integrated into a powerful whole" (d. 11). The suggested reform plan should observe both quantity and quality, balancing between content and facilities at the same time.

In addition to providing the reader with an insightful analysis of the ummah's current dilemma, as a former IIUM rector, AbuSulayman uses the example of IIUM as a suggested model of correction. Through an insider's eyes, he gives detailed background information about the project so readers can grasp the multi-dimensional nature of the needed actions.

IIUM is designed to meet the spiritual, psychological, and cognitive needs of its 15,000 Muslim students. Its two campuses, the main one in Kuala Lumpur and the medical campus in Kuantan, are among the most elegant in the world and are designed to express the university's ideology: the Islamization of knowledge. The mosque is purposely situated at the center of the main campus to symbolize the importance of spiritual enrichment in university life. Seeking to serve both soul and body, the recreational facilities allow maximum freedom for both sexes while simultaneously observing the Islamic concepts of morality in gender relations.

As for its academic and curricular systems, IIUM provides a unique example of the duality of knowledge and specialization. Under its doublemajor systems, students majoring in Islamic studies are required to major in a second social science of their choice and vice versa. Students are also encouraged to study their second major for an extra year so that they will graduate with a second bachelor's degree. This dual system not only ensures the quality of education offered, but also provides them with more job opportunities in the fields of the Islamic and social sciences. Additionally, the dual system provides bilingual professional training in English (the language of instruction for social science subjects) and Arabic (the language of 
instruction for Islamic subjects). Moreover, many undergraduate and postgraduate courses are designed to develop the students' awareness of the ummah's current needs and concerns. These courses, offered through different departments and disciplines, are studied within various majors. Western studies is also a growing major that enables students to understand the history, culture, and relationship between the West and the ummah.

IIUM is funded by the government, in addition to the many private national and international contributors who see it as a budding successful experiment that deserves both financial and spiritual support. I strongly recommend the book to all Muslim educators and non-educators as well, for it gives hope and aspiration of a better and brighter future for the ummah.

Hadeer A. Nagah

Professor, Women Studies Institute University of Ottawa, Canada Visiting Scholar, Pauline Jewett Institute of Women's Studies

Carleton University, Ottawa, Canada 